$<$ Supporting Information $>$

\title{
Suprachannel as a Radical Trap: Crystal Structure of Single Carbon Radicals
}

\author{
Yoonjung Cho, Tae Hwan Noh, Jeong Gyun Kim, Haeri Lee, and Ok-Sang Jung* \\ Department of Chemistry, Pusan National University, Pusan 609-735, Korea
}

\section{EXPERIMENTAL}

Materials and Measurements. All commercialized chemicals including 2,3-

dihydroxynaphthalene and $\mathrm{ZnI}_{2}$ were purchased from Aldrich and used without further purification. 2,3-Bis(isonicotonoyloxy)naphthalene (L) was prepared according to the published procedure. ${ }^{1}$ Elemental microanalyses $(\mathrm{C}, \mathrm{H}, \mathrm{N})$ were performed on solid samples at the Pusan Center, KBSI, using a Vario-EL III. FT-IR spectra were obtained on a Nicolet 380 FT-IR spectrometer with samples prepared as $\mathrm{KBr}$ pellets. Thermal analyses were performed under $\mathrm{N}_{2}$ at a scan rate of $10{ }^{\circ} \mathrm{C} / \mathrm{min}$ using a Labsys TGA-DSC 1600 . UV-vis spectra were acquired on a Shimadzu UV-1800. FT-Raman spectra were obtained by Vertex $80 \mathrm{~V}$ Microscopic FT-IR/Raman Spectrometer (Bruker, Germany) with a Nd:YAG laser (100 mW, $1064 \mathrm{~nm}$ ), at KBSI Busan Center, Korea. ${ }^{1} \mathrm{H}(300 \mathrm{MHz})$ NMR spectra were recorded on a Varian Mercury Plus 300 with calibration against the solvent signal $\left(\mathrm{Me}_{2} \mathrm{SO}-d_{6}: \delta=2.50\right.$ ppm). Solid-state ${ }^{13} \mathrm{C}(150.833 \mathrm{MHz})$ NMR experiments were carried out in a ${ }^{\text {(unity) Inova }}$ spectrometer (Agilent Tech., USA) operating with a $5 \mathrm{~mm}$ probe head at a frequency of 150.833 MHz, at KBSI Western Seoul Center, Korea. The samples were filled into zirconia rotors, and all the experiments were carried out at spinning frequencies of $10 \mathrm{kHz}$, using 
typical cross-polarization times of $3 \mathrm{~ms}$. The pulse repetition time was 6 seconds and 1024 scans were accumulated. $90^{\circ}$ pulse was set to $5 \mu$ s. An excitation method based on ${ }^{1} \mathrm{H}^{-13} \mathrm{C}$ cross-polarization with a radio frequency ramp, denoted here simply as CPMAS, was used to achieve a good signal to noise ratio, combined with a uniform excitation among the different chemical groups. ${ }^{2}$ Chemical shifts were referred to TMS (tetramethylsilane) by setting the methyl signal of HMB (hexamethylbenzene) at $17.3 \mathrm{ppm}$. Spinning sidebands were avoided using TOSS scheme with composite pulses, as described in the literature. ${ }^{3}$ All EPR measurements were carried out at KBSI Western Seoul Center, Korea. CW X-band (9.64 GHz) EPR spectra were collected on a Bruker EMX plus 6/1 spectrometer equipped with an Oxford Instrument ESR 900 liquid He cryostat using an Oxford ITC 503 temperature controller. All spectra were collected with the following experimental parameters: microwave power, $0.94 \mathrm{~mW}$; modulation amplitude, $10 \mathrm{G}$; 5 scans; temperature, $5 \mathrm{~K}$. XPS data were collected using an X-ray photoelectron spectrometer AR-XPS system (Thermo Fisher Scientific, UK) at KBSI Busan Center, Korea, employing Al K $\alpha$ radiation (1486.6 eV), and the spectra were calibrated according to the binding energy of the $\mathrm{C}_{1 s}$ peak at $284.6 \mathrm{eV}$. UV photoelectron spectra (UPS) were recorded by an AXIS Ultra DLD (KRATOS Inc., UK), at KBSI Daejeon Center, Korea, using He I $\alpha(21.2 \mathrm{eV})$ ionization under $4.0 \times 10^{-8}$ Torr. Synthesis of $\mathbf{C H}_{2} \mathbf{C l}_{2} @\left[\mathbf{Z n I}_{2} \mathbf{L}\right]_{2}$. An ethanol solution (8 mL) of $\mathrm{ZnI}_{2}(0.12 \mathrm{mmol}, 38 \mathrm{mg})$ was layered onto a dichloromethane solution $(8 \mathrm{~mL})$ of $\mathrm{L}(0.12 \mathrm{mmol}, 44 \mathrm{mg})$. After 3 days, colorless crystals suitable for single crystal X-ray diffraction were obtained in a $91 \%$ yield (160 mg) based on zinc(II) salt. Mp: $355^{\circ} \mathrm{C}$ (dec.). Anal. Calcd for $\mathrm{C}_{45} \mathrm{H}_{30} \mathrm{~N}_{4} \mathrm{O}_{8} \mathrm{Cl}_{2} \mathrm{I}_{4} \mathrm{Zn}_{2}$ : C 36.92, H 2.07, N 3.83. Found: C 36.70, H 2.11, N 3.78.IR (KBr pellet, $\left.\mathrm{cm}^{-1}\right)$ : 3049(w), 1767(s), 1749(m), 1620(w), 1510(w), 1421(m), 1362(w), 1279(s), 1250(s), 1147(m), 1115(m), 1063(m), 1024(m), 901(w), 754(w), 692(w), 654(w), 480(w). 
Synthesis of 1.5CH $\mathrm{H}_{2} \mathrm{Br}_{2} @\left[\mathrm{ZnI}_{2} \mathrm{~L}_{2} \cdot \mathbf{2 C H}_{2} \mathrm{Br}_{2} \cdot 1.5 \mathrm{CH}_{2} \mathrm{Br}_{2} @\left[\mathrm{ZnI}_{2} \mathrm{~L}\right]_{2} \cdot 2 \mathrm{CH}_{2} \mathrm{Br}_{2}\right.$ was prepared in the same manner as the above $\mathrm{CH}_{2} \mathrm{Cl}_{2} @\left[\mathrm{ZnI}_{2} \mathrm{~L}\right]_{2}$, except that dibromomethane was employed instead of dichloromethane. After 5 days, colorless crystals suitable for single crystal X-ray diffraction were obtained in a $88 \%$ yield $(72 \mathrm{mg})$ based on zinc(II) salt. Mp: $346{ }^{\circ} \mathrm{C}$ (dec.). Anal. Calcd for $\mathrm{C}_{46.5} \mathrm{H}_{33} \mathrm{~N}_{4} \mathrm{O}_{8} \mathrm{Br}_{5} \mathrm{I}_{4} \mathrm{Zn}_{2}$ : C 30.79, H 1.83, N 3.09. Found: $\mathrm{C}$ 31.00, H 1.88, N 3.05. IR (KBr pellet, $\mathrm{cm}^{-1}$ ): 1767(m), 1618(w), 1558(w), 1508(w), 1468(w), 1421(m), 1362(w), 1329(w), 1271(s), 1171(w), 1146(m), 1090(m), 1061(m), 1024(m), 895(w), 852(w), 754(m), 692(m), 634(w), 480(w).

Synthesis of $\mathbf{C H}_{2} \mathbf{I}_{2} @\left[Z_{\mathbf{n I}} \mathbf{L}\right]_{\mathbf{2}} \cdot \mathbf{2 C H}_{\mathbf{2}} \mathbf{I}_{2}$. An ethanol solution $(2 \mathrm{~mL})$ of $\mathrm{ZnI}_{2}(0.03 \mathrm{mmol}, 9.6$ $\mathrm{mg})$ was layered onto a mixture of dichloromethane and diiodomethane solution $(v / v=3: 1,2$ $\mathrm{mL})$ of L ( $0.03 \mathrm{mmol}, 11 \mathrm{mg})$. After 4 days, pale-yellow crystals suitable for single crystal Xray diffraction were obtained in a $89 \%$ yield $(10 \mathrm{mg})$ based on zinc(II) salt. Mp: $352{ }^{\circ} \mathrm{C}$ (dec.). Anal. Calcd for $\mathrm{C}_{47} \mathrm{H}_{34} \mathrm{~N}_{4} \mathrm{O}_{8} \mathrm{I}_{10} \mathrm{Zn}_{2}$ : C 25.86, H 1.57, N 2.57. Found: C 25.50, H 1.55, N 2.56. IR (KBr pellet, $\mathrm{cm}^{-1}$ ): 3045(w), 1751(m), 1618(w), 1560(w), 1541(w), 1508(m), 1466(w), 1419(m), 1362(w), 1273(s), 1250(s), 1169(w), 1144(w), 1090(m), 1059(m), 1024(w), 899(w), 756(m), 692(w), 609(m), 571(w).

X-ray Crystal Structure Determinations. X-ray data were collected on a Bruker SMART automatic diffractometer with a graphite-monochromated Mo $\mathrm{K} \alpha(\lambda=0.71073 \AA)$ and a CCD detector at $-25{ }^{\circ} \mathrm{C}$. Thirty-six frames of two-dimensional diffraction images were collected and processed to obtain the cell parameters and orientation matrix. The data were corrected for Lorentz and polarization effects. Absorption effects were corrected by the multi-scan method (SADABS). ${ }^{4}$ The structures were solved by the direct method (SHELXS 97) ${ }^{5}$ and refined by full-matrix least squares techniques (SHELXL 2014/7). ${ }^{6}$ The non-hydrogen atoms were refined anisotropically, and hydrogen atoms were placed in calculated positions and 
refined only for the isotropic displacement parameters. The crystal parameters and procedural information corresponding to the data collection and structure refinement are listed in Table S1.

Discrimination of Dihalomethane Molecules. All of the solvate molecules of the present zinc(II) compound could be removed at $90{ }^{\circ} \mathrm{C}$ in vacuum, as confirmed by reference to the IR, elemental analysis, and ${ }^{1} \mathrm{H}$ NMR results. The evacuated $\left[\mathrm{ZnI}_{2} \mathrm{~L}\right]_{2}$ was immersed in a mixture of $\mathrm{CH}_{2} \mathrm{Cl}_{2}, \mathrm{CH}_{2} \mathrm{Br}_{2}$, and $\mathrm{CH}_{2} \mathrm{I}_{2}(v / v / v=1: 1: 1,3 \mathrm{~mL})$ for 1 day. The ${ }^{1} \mathrm{H}$ NMR spectrum of the immersed sample was measured in $\mathrm{Me}_{2} \mathrm{SO}-d_{6}$ in order to confirm the incorporation of dihalomethane molecules, even though each compound was dissociated in the solution.

Photoreaction of $\mathrm{CH}_{2} \mathrm{I}_{2} @\left[\mathrm{ZnI}_{2} \mathrm{~L}\right]_{2} \cdot \mathbf{2 C H}_{2} \mathrm{I}_{2}$. The crystalline solids of $\mathrm{CH}_{2} \mathrm{I}_{2} @\left[\mathrm{ZnI}_{2} \mathrm{~L}\right]_{2} \cdot 2 \mathrm{CH}_{2} \mathrm{I}_{2}$ were exposure to the $350 \mathrm{~nm} \mathrm{UV}$-irradiation by using LZC-4V Photoreactor (Luzchem Res., Inc.) with the intensity of $1.75 \mathrm{~mW} \mathrm{~cm}^{-2}$ at ambient temperature.

\section{References for the Experimental Section}

(1) Cho, Y.; Kim, J. G.; Noh, T. H.; Jung, O.-S. J. Mol. Struct. 2013, 1047, 95.

(2) Cook, R. L. Anal. Bioanal. Chem. 2004, 378, 1484.

(3) Novotny, E. H.; deAzevedo, E. R.; Bonagamba, T. J.; Cunha, T. J. F.; Madari, B. E.; Benites, V. de M.; Hayes, M. H. B. Environ. Sci. Technol. 2007, 41, 400.

(4) Sheldrick, G. M. SADABS: A Program for Empirical Absorption Correction of Area Detector Data; University of Göttingen, Göttingen, Germany, 1996.

(5) Sheldrick, G. M. SHELXS-97: A Program for Structure Determination; University of Göttingen, Göttingen, Germany, 1997.

(6) Sheldrick, G. M. SHELXL-2014/7: A Program for Structure Refinement; University of Göttingen, Göttingen, Germany, 2014. 
Table S1. Crystal Data and Structural Refinement Parameters of $\mathrm{CH}_{2} \mathrm{Cl}_{2} @\left[\mathrm{ZnI}_{2} \mathrm{~L}\right]_{2}$, $1.5 \mathrm{CH}_{2} \mathrm{Br}_{2} @\left[\mathrm{ZnI}_{2} \mathrm{~L}\right]_{2} \cdot 2 \mathrm{CH}_{2} \mathrm{Br}_{2}, \mathrm{CH}_{2} \mathrm{I}_{2} @\left[\mathrm{ZnI}_{2} \mathrm{~L}\right]_{2} \cdot 2 \mathrm{CH}_{2} \mathrm{I}_{2}$, and $\left(0.3 \cdot \mathrm{CH}_{2} \mathrm{I}+0.85\right.$

$\left.\mathrm{I}_{2}\right) @\left[\mathrm{ZnI}_{2} \mathrm{~L}\right]_{2} \cdot 2 \mathrm{CH}_{2} \mathrm{I}_{2}$

\begin{tabular}{|c|c|c|c|c|}
\hline & $\mathrm{CH}_{2} \mathrm{Cl}_{2} @\left[\mathrm{ZnI}_{2} \mathrm{~L}\right]_{2}$ & $\begin{array}{c}1.5 \mathrm{CH}_{2} \mathrm{Br}_{2} @\left[\mathrm{ZnI}_{2} \mathrm{~L}\right]_{2} \cdot- \\
2 \mathrm{CH}_{2} \mathrm{Br}_{2}\end{array}$ & $\begin{array}{c}\mathrm{CH}_{2} \mathrm{I}_{2} @\left[\mathrm{ZnI}_{2} \mathrm{~L}\right]_{2} \cdot- \\
2 \mathrm{CH}_{2} \mathrm{I}_{2}\end{array}$ & $\begin{array}{c}\left(0.3 \cdot \mathrm{CH}_{2} \mathrm{I}+0.85 \mathrm{I}_{2}\right) @- \\
{\left[\mathrm{ZnI}_{2} \mathrm{~L}\right]_{2} \cdot 2 \mathrm{CH}_{2} \mathrm{I}_{2}}\end{array}$ \\
\hline Formula & $\mathrm{C}_{45} \mathrm{H}_{30} \mathrm{~N}_{4} \mathrm{O}_{8} \mathrm{Cl}_{2} \mathrm{Zn}_{2} \mathrm{I}_{4}$ & $2 \mathrm{C}_{47.5} \mathrm{H}_{35} \mathrm{~N}_{4} \mathrm{O}_{8} \mathrm{Zn}_{2} \mathrm{Br}_{7} \mathrm{I}_{4}$ & $\mathrm{C}_{47} \mathrm{H}_{34} \mathrm{~N}_{4} \mathrm{O}_{8} \mathrm{Zn}_{2} \mathrm{I}_{10}$ & $\mathrm{C}_{46.3} \mathrm{H}_{32.6} \mathrm{~N}_{4} \mathrm{O}_{8} \mathrm{Zn}_{2} \mathrm{I}_{10}$ \\
\hline$M_{\mathrm{w}} / \mathrm{g} \mathrm{mol}^{-1}$ & 1463.97 & 3975.01 & 2182.52 & 2172.70 \\
\hline Cryst. system & Monoclinic & Triclinic & Triclinic & Triclinic \\
\hline Space group & $P 2_{1} / c$ & $P-1$ & $P-1$ & $P-1$ \\
\hline$a / \AA$ & $8.9460(2)$ & $10.8620(3)$ & $9.8298(2)$ & $9.8178(4)$ \\
\hline$b / \AA$ & $9.9120(2)$ & $15.1671(4)$ & $10.8356(2)$ & $10.8905(5)$ \\
\hline$c / \AA$ & $27.6572(6)$ & $20.1107(5)$ & $15.0666(3)$ & $15.1136(6)$ \\
\hline$\alpha /{ }^{\circ}$ & 90 & $110.596(1)$ & $95.587(1)$ & $95.665(2)$ \\
\hline$\beta /{ }^{\circ}$ & $90.759(1)$ & $105.020(1)$ & $96.717(1)$ & $97.119(2)$ \\
\hline$\gamma / 0$ & 90 & $91.954(1)$ & $97.680(1)$ & $97.681(2)$ \\
\hline$V / \AA^{3}$ & $2452.22(9)$ & $2966.5(1)$ & $1569.02(5)$ & $1578.2(1)$ \\
\hline$\sigma / \mathrm{g} \mathrm{cm}^{-1}$ & 1.983 & 2.225 & 2.310 & 2.286 \\
\hline$Z$ & 2 & 1 & 1 & 1 \\
\hline$\mu / \mathrm{mm}^{-1}$ & 3.660 & 7.655 & 5.731 & 5.697 \\
\hline$F(000)$ & 1396 & 1858 & 998 & 992 \\
\hline Data collected & 35996 & 48544 & 24547 & 24373 \\
\hline$R_{\text {int }}$ & 0.0968 & 0.1250 & 0.1136 & 0.1031 \\
\hline Parameters & 298 & 658 & 331 & 334 \\
\hline Completeness / \% & 100.0 & 99.8 & 99.9 & 100.0 \\
\hline GoF on $F^{2}$ & 1.028 & 1.060 & 1.054 & 1.053 \\
\hline$R_{1}[I>2 \sigma(I)]^{\mathrm{a}}$ & 0.0353 & 0.0784 & 0.0657 & 0.0786 \\
\hline$w R_{2}$ (all data) ${ }^{\mathrm{b}}$ & 0.0986 & 0.2498 & 0.2060 & 0.2362 \\
\hline
\end{tabular}

${ }^{\mathrm{a}} R_{1}=\Sigma|| F_{\mathrm{o}}|-| F_{\mathrm{c}}|/ \Sigma| F_{\mathrm{o}} \mid \cdot{ }^{\mathrm{b}} w R_{2}=\left(\Sigma\left[w\left(F_{\mathrm{o}}{ }^{2}-F_{\mathrm{c}}{ }^{2}\right)^{2}\right] / \Sigma\left[w\left(F_{\mathrm{o}}{ }^{2}\right)^{2}\right]\right)^{1 / 2}$. 


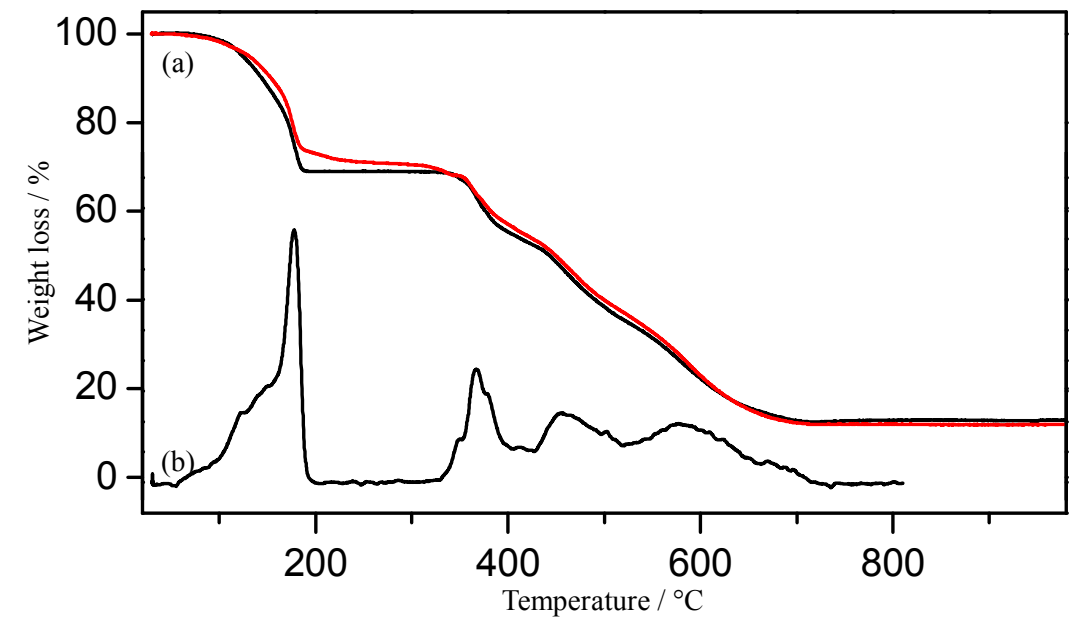

Figure S1. TGA curves (a) of $\mathrm{CH}_{2} \mathrm{I}_{2} @\left[\mathrm{ZnI}_{2} \mathrm{~L}\right]_{2} \cdot 2 \mathrm{CH}_{2} \mathrm{I}_{2}$ (black line) and $\left(0.3 \cdot \mathrm{CH}_{2} \mathrm{I}+0.85\right.$ $\left.\mathrm{I}_{2}\right) @\left[\mathrm{ZnI}_{2} \mathrm{~L}\right]_{2} \cdot 2 \mathrm{CH}_{2} \mathrm{I}_{2}$ (red line). Differential TGA curves (b) of $\mathrm{CH}_{2} \mathrm{I}_{2} @\left[\mathrm{ZnI}_{2} \mathrm{~L}\right]_{2} \cdot 2 \mathrm{CH}_{2} \mathrm{I}_{2}$ showing two-step evaporation of "outside" and "inside" $\mathrm{CH}_{2} \mathrm{I}_{2}$ solvate molecules in the $105-160$ and $160-190{ }^{\circ} \mathrm{C}$ ranges, respectively. 

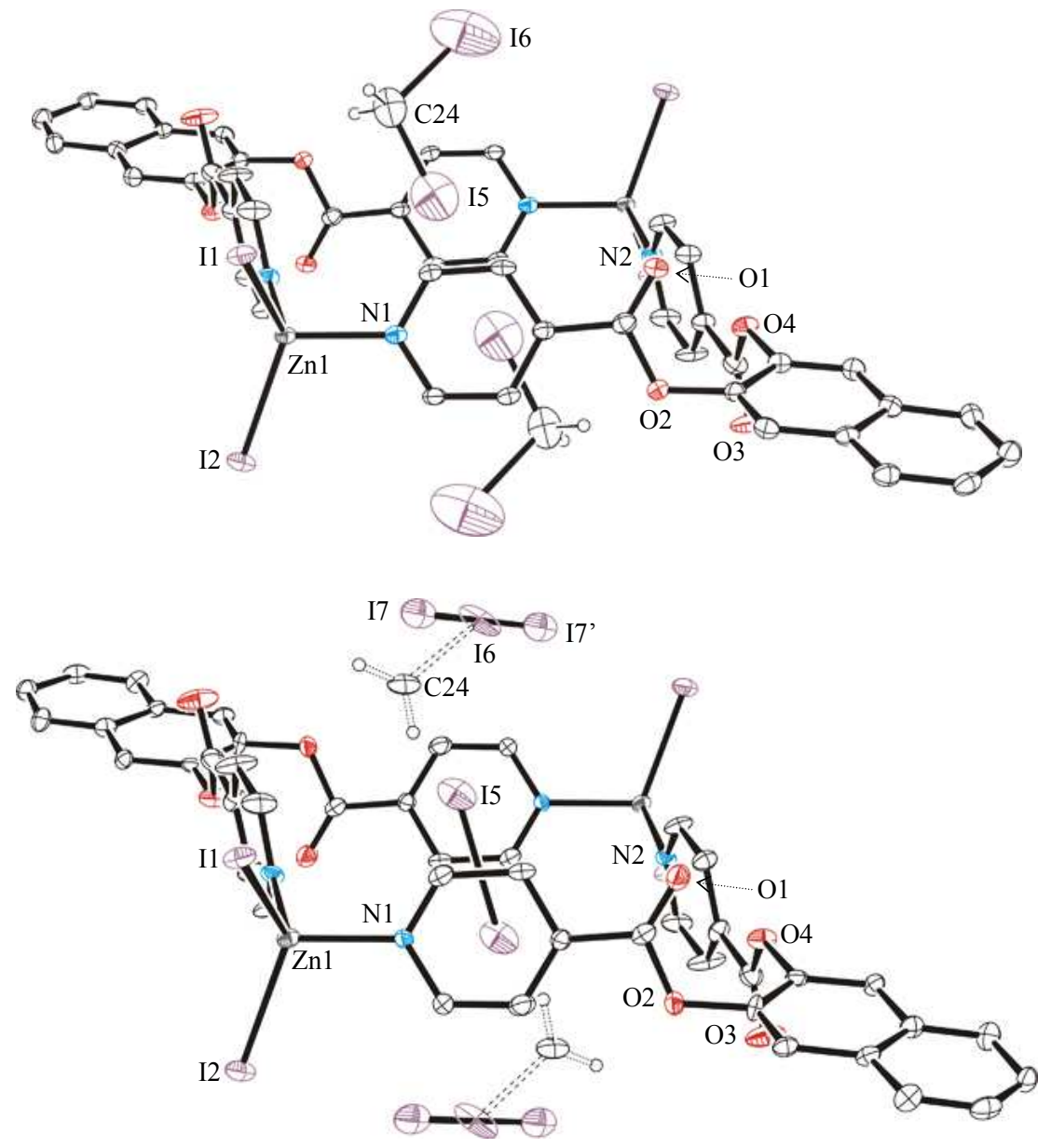

Figure S2. ORTEP drawings of $\mathrm{CH}_{2} \mathrm{I}_{2} @\left[\mathrm{ZnI}_{2} \mathrm{~L}\right]_{2} \cdot 2 \mathrm{CH}_{2} \mathrm{I}_{2}$ (top) and $\left(0.3 \cdot \mathrm{CH}_{2} \mathrm{I}+0.85\right.$

$\left.\mathrm{I}_{2}\right) @\left[\mathrm{ZnI}_{2} \mathrm{~L}\right]_{2} \cdot 2 \mathrm{CH}_{2} \mathrm{I}_{2}$ (bottom) with anisotropic displacement parameters at $30 \%$ probability. Hydrogen atoms in metallacyclodimers and simply solvate diiodomethane molecules were omitted for clarity. According to the single crystal X-ray diffraction measurement, for $\mathrm{CH}_{2} \mathrm{I}_{2} @\left[\mathrm{ZnI}_{2} \mathrm{~L}\right]_{2} \cdot 2 \mathrm{CH}_{2} \mathrm{I}_{2}$, the occupancies of $\mathrm{C}(24), \mathrm{I}(5)$, and $\mathrm{I}(6)$ corresponding to the "inside" $\mathrm{CH}_{2} \mathrm{I}_{2}$ are 0.5 . On the other hand, in case of $\left(0.3 \cdot \mathrm{CH}_{2} \mathrm{I}+0.85 \mathrm{I}_{2}\right) @\left[\mathrm{ZnI}_{2} \mathrm{~L}\right]_{2} \cdot 2 \mathrm{CH}_{2} \mathrm{I}_{2}$, the occupancy of $\mathrm{I}(5)$ is 0.5 whereas those of $\mathrm{C}(24)$ and $\mathrm{I}(6)$ corresponding to $\mathrm{CH}_{2} \mathrm{I}$ are 0.15 and that of $\mathrm{I}(7)$ is 0.35 . 

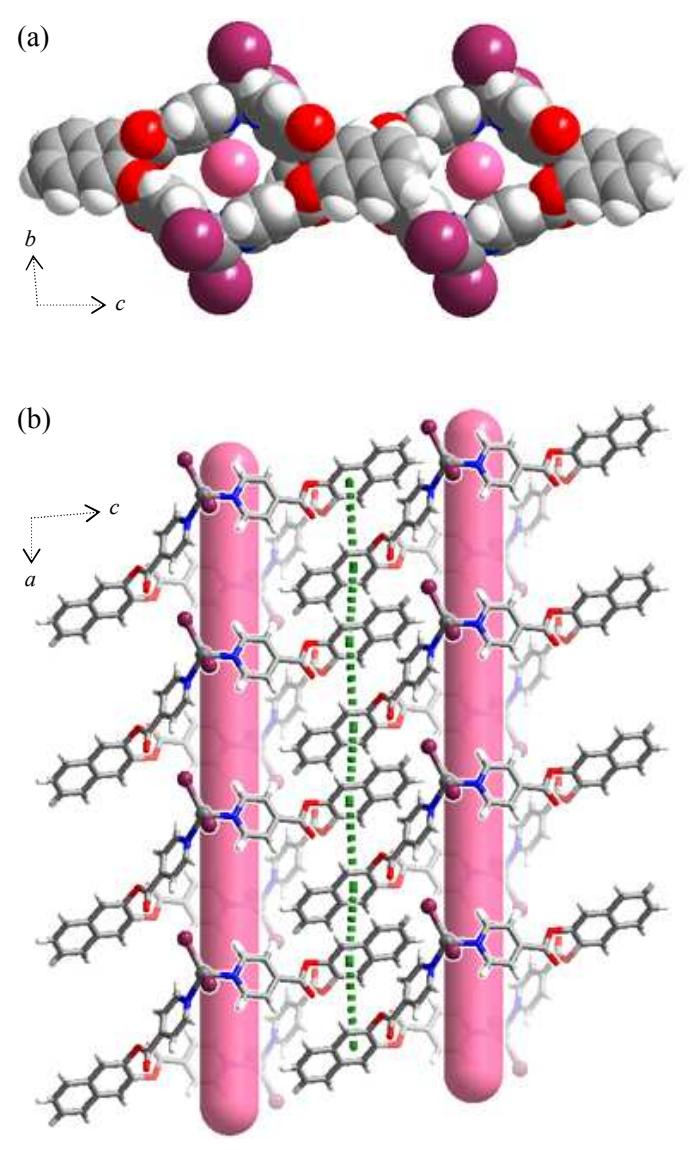

Figure S3. Top (a) and side (b) views of $\mathrm{CH}_{2} \mathrm{I}_{2} @\left[\mathrm{ZnI}_{2} \mathrm{~L}\right]_{2} \cdot 2 \mathrm{CH}_{2} \mathrm{I}_{2}$ showing suprachannels and interdigitated $\pi \cdots \pi$ interactions represented as pink and green colors, respectively. Solvated diiodomethane molecules were omitted for clarity. The diameter of the dummy pillars is 3.6 Å. 


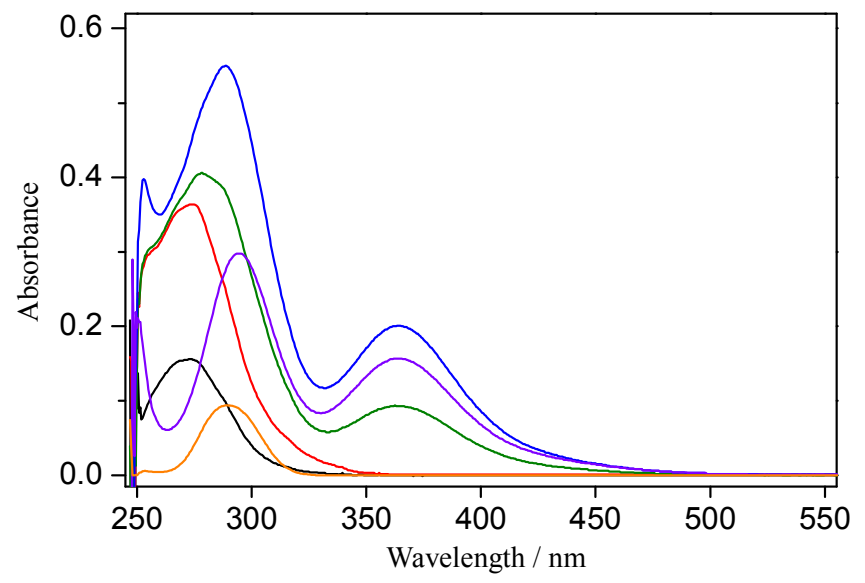

Figure S4. Absorption spectra of $\mathrm{CH}_{2} \mathrm{I}_{2} @\left[\mathrm{ZnI}_{2} \mathrm{~L}\right]_{2} \cdot 2 \mathrm{CH}_{2} \mathrm{I}_{2}$ in a mixed dimethyl sulfoxide/methanol solution $\left(10^{-5} M\right)$ upon photoreaction for 0 day (red), 7 days (green), and 14 days (blue lines). The spectra with black, orange, and violet colors correspond to $\mathrm{L}, \mathrm{CH}_{2} \mathrm{I}_{2}$, and the authentic $\mathrm{I}_{2}$, respectively. 


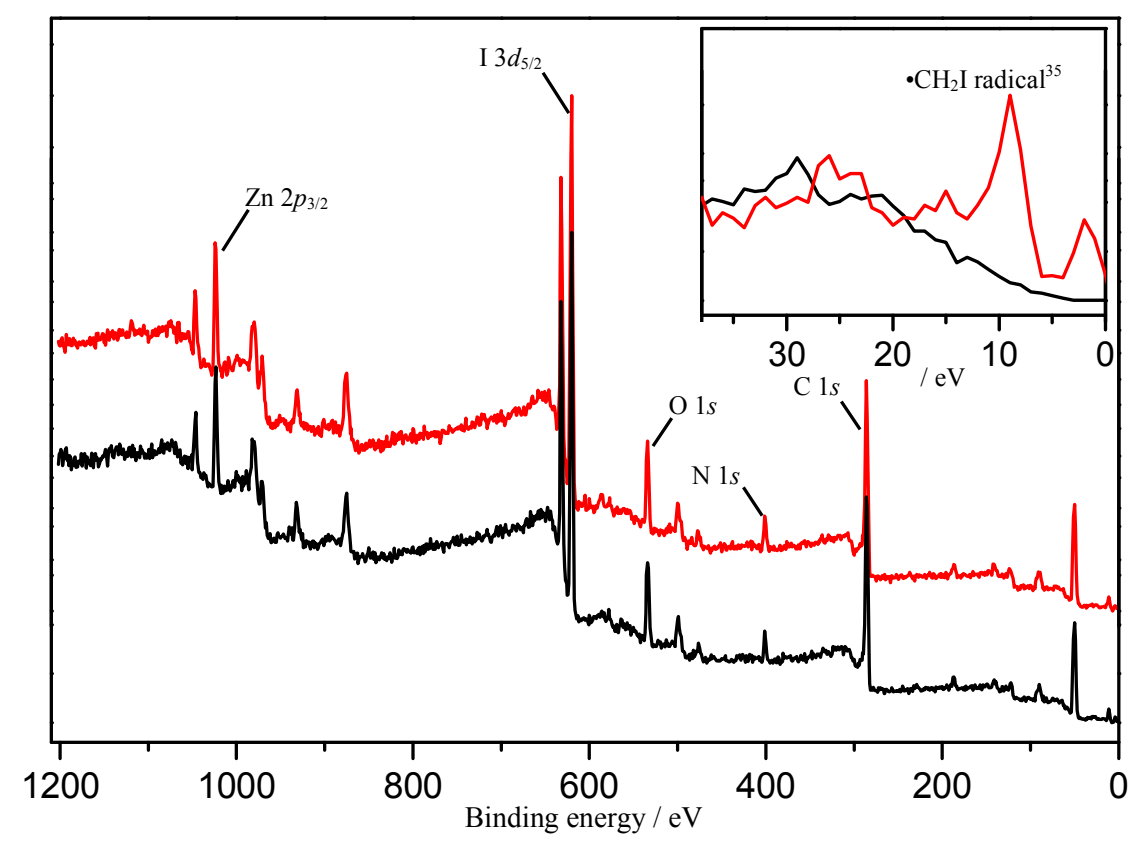

Figure S5. XPS and UPS (inset) spectra of $\mathrm{CH}_{2} \mathrm{I}_{2} @\left[\mathrm{ZnI}_{2} \mathrm{~L}\right]_{2} \cdot 2 \mathrm{CH}_{2} \mathrm{I}_{2}$ (black) and $\left(0.3 \cdot \mathrm{CH}_{2} \mathrm{I}+\right.$ $\left.0.85 \mathrm{I}_{2}\right) @\left[\mathrm{ZnI}_{2} \mathrm{~L}\right]_{2} \cdot 2 \mathrm{CH}_{2} \mathrm{I}_{2}$ (red lines). 


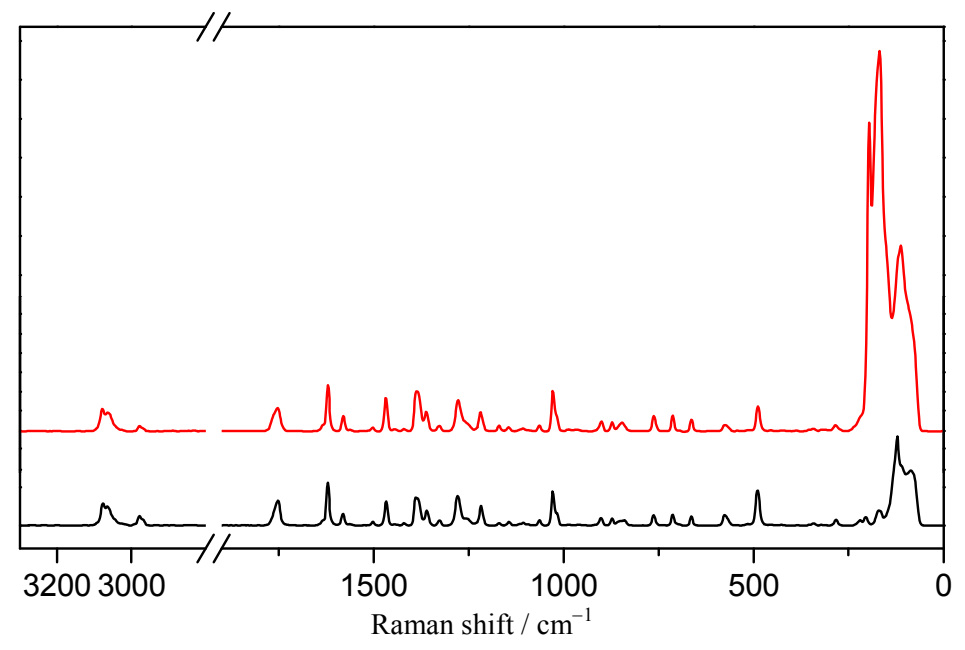

Figure S6. Full data of Raman spectra for $\mathrm{CH}_{2} \mathrm{I}_{2} @\left[\mathrm{ZnI}_{2} \mathrm{~L}\right]_{2} \cdot 2 \mathrm{CH}_{2} \mathrm{I}_{2}$ (black) and $\left(0.3 \cdot \mathrm{CH}_{2} \mathrm{I}+\right.$ $\left.0.85 \mathrm{I}_{2}\right) @\left[\mathrm{ZnI}_{2} \mathrm{~L}\right]_{2} \cdot 2 \mathrm{CH}_{2} \mathrm{I}_{2}$ (red line). 


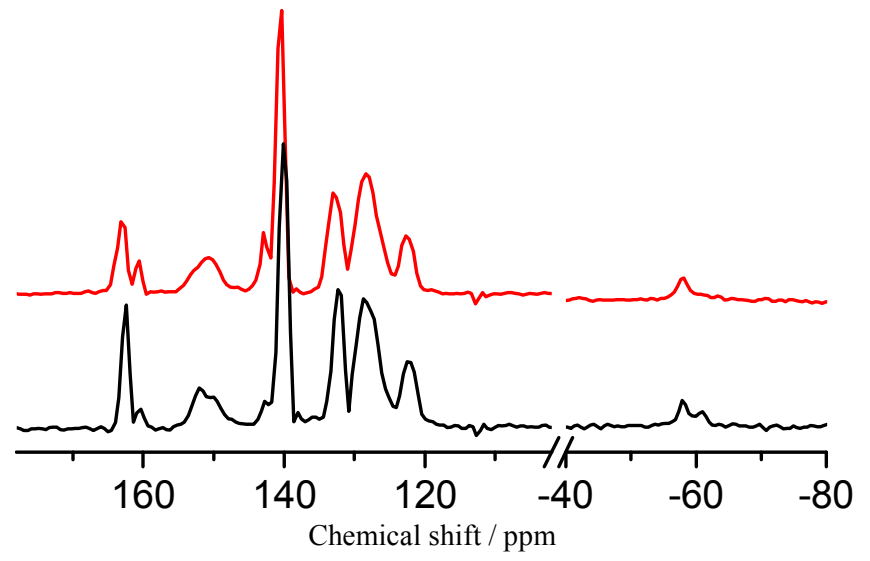

Figure S7. Full data of ${ }^{13} \mathrm{C}$ CP-MAS-TOSS spectra for $\mathrm{CH}_{2} \mathrm{I}_{2} @\left[\mathrm{ZnI}_{2} \mathrm{~L}\right]_{2} \cdot 2 \mathrm{CH}_{2} \mathrm{I}_{2}$ (black) and $\left(0.3 \cdot \mathrm{CH}_{2} \mathrm{I}+0.85 \mathrm{I}_{2}\right) @\left[\mathrm{ZnI}_{2} \mathrm{~L}\right]_{2} \cdot 2 \mathrm{CH}_{2} \mathrm{I}_{2}$ (red line). 


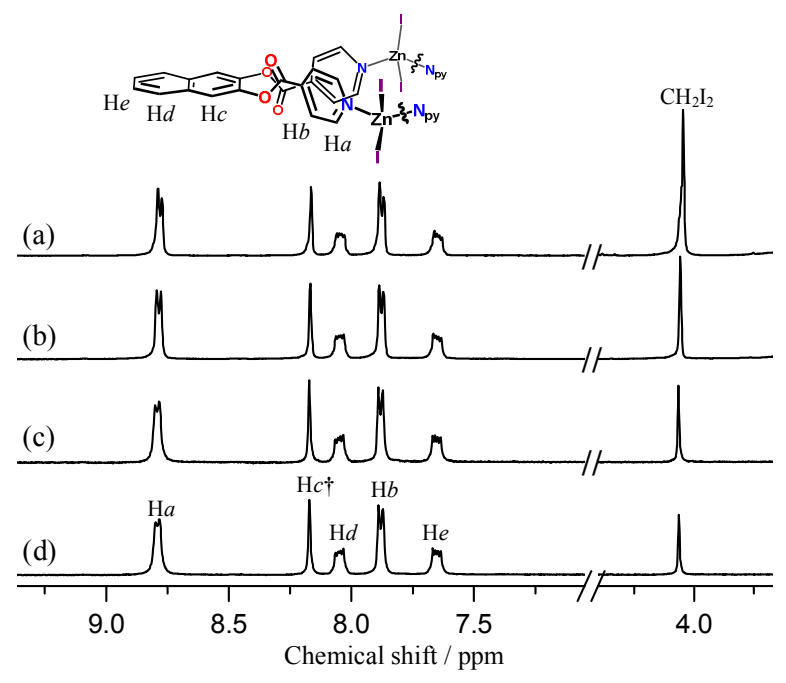

Figure S8. ${ }^{1} \mathrm{H}$ NMR spectra of $\mathrm{CH}_{2} \mathrm{I}_{2} @\left[\mathrm{ZnI}_{2} \mathrm{~L}\right]_{2} \cdot 2 \mathrm{CH}_{2} \mathrm{I}_{2}$ (a) along with the assignment and its $350 \mathrm{~nm}-\mathrm{UV}$-irradiated samples for 4 days (b), 7 days (c), and 14 days (d) showing decreases in $\mathrm{CH}_{2} \mathrm{I}_{2}$ solvate molecule amount with increasing photoreaction time. The dagger corresponding to $\mathrm{Hc}$ protons of $\mathrm{L}$ was used as an integral reference. 


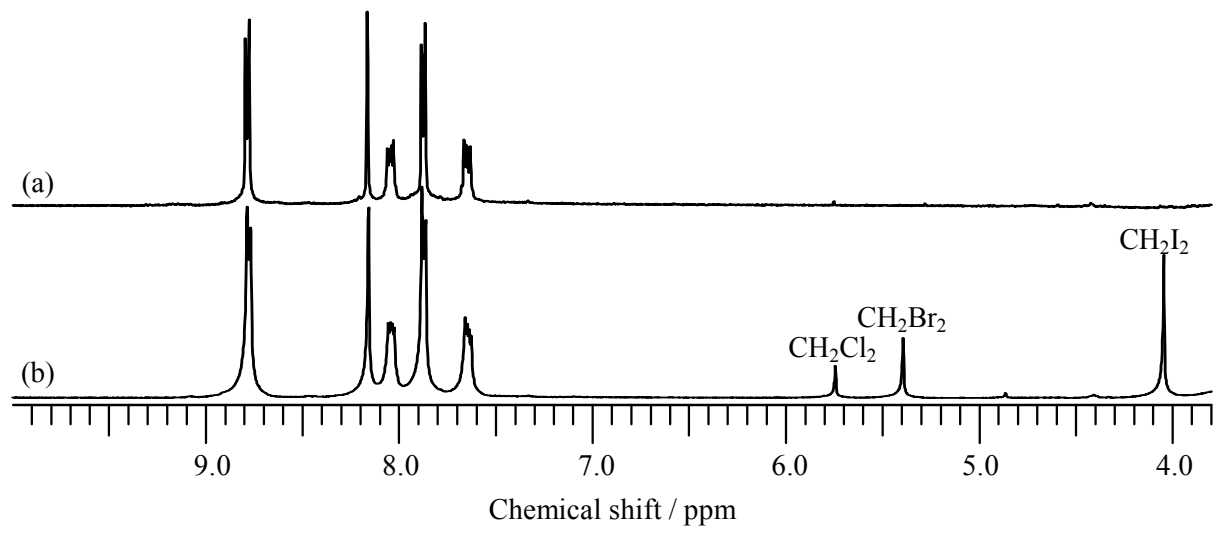

Figure S9. ${ }^{1} \mathrm{H}$ NMR $\left(\mathrm{Me}_{2} \mathrm{SO}-d_{6}\right)$ spectra of the evacuated sample, $\left[\mathrm{ZnI}_{2} \mathrm{~L}\right]_{2}(\mathrm{a})$, and reabsorbed (b) sample via immersion in a mixed $\mathrm{CH}_{2} \mathrm{Cl}_{2}, \mathrm{CH}_{2} \mathrm{Br}_{2}$, and $\mathrm{CH}_{2} \mathrm{I}_{2}(v / v / v=1: 1: 1)$ for 1 day. The absorbed solvate molecules' ratio is $1: 2: 6$. 